DOI http://dx.doi.org/10.18551/rjoas.2016-08.13

\title{
AGROCHEMICAL EFFECT OF BACTERIA FERTILIZER ON CARROT (DAUCUS CAROTA L.) CULTIVATION
}

\author{
Lantos Ferenc* \\ Plant Science and Environment Protection Institute, University of Szeged, Hungary \\ *E-mail: lantos@mgk.u-szeged.hu \\ Papp Zoltán \\ Dr. Bugyi István Hospital, Szentes, Hungary \\ E-mail: pappzoltandr@index.hu \\ Szűcs Bence, Hódiné Margit Szél \\ Faculty of Agriculture, University of Szeged, Hungary \\ E-mail: szucsi9108@freemail.hu, hodine@mgk.u-szeged.hu
}

\begin{abstract}
Usually, the success of growing is determined by the quality and market value of vegetables. The quality commodity production is also expected by the market. The really good vegetable contains a number of biological nutrients that are easy to process and easily digestible and it can provide culinary delights for the consumer. In Hungary the cultivation of carrot (Daucus carota L.) has a centuries-old tradition, but often raises the question as to the most effective nutrient supply technology during its growing. According to this, the determination of the correct nutrient supply and the selection of the variety are professional challenges. Our aim was analyzing and presenting the different variety-based nutrient supply methods based on small size parcels. At the end of our observation we determined the biochemical mechanism of the uptake of several nutrients and their agrochemical importance in correlation of nutrientsupply methods and the meteorological and soil condition of the cultivation area. Our further aim was analyzing and justifying the most effective nutrient supply of Napa $F_{1}$ carrot hybrid.
\end{abstract}

\section{KEY WORDS}

Carrot (Daucus carota L.), water-soluble carbohydrates, carotene, bacteria fertilizer.

Considering its carnitine, carbohydrate and volatile oil content the carrot is (Daucus carota L.) one of the most valuable vegetables. The cultivated carrot contains $88 \%$ water, $7 \%$ sugar, $1 \%$ protein, $1 \%$ fiber, $1 \%$ ash and $0.2 \%$ fat in average. Its carotene content is outstanding, at least $90 \%(\alpha, \beta)$ carotenes, which are considered provitamins-A. The carotene is a collective name of the molecules formula of $\mathrm{C}_{40} \mathrm{H}_{56}$. Fats and fat solvent materials they are readily soluble but insoluble in water, therefore called lipochrome. On that basis two major isomers are known as $\alpha$ - and $\beta$-carotene, but there are also gamma, delta and epsilon- ( $\gamma, \delta$ and $\varepsilon$ - carotene) version as well (Olson, 2006). So far, more than 600 carotenoids have been isolated. The five most important carotenoids are: beta-carotene, the a-carotene, beta-kryptoxanthin, lutein and lycopene (Linus Pauling Institute, 2009). The carotenoids are present closely bound to chlorophyll as coral-colored pigments. Generated energy is transmitted by their light absorption properties to the center of the photochemical reaction system (Láng, 2003). In addition to carotenoids the carrot contains lycopene and xanthophyll; they are well-known about antioxidant action. Among the water-soluble vitamins $\mathrm{B} 1, \mathrm{~B} 2, \mathrm{~B} 3, \mathrm{~B} 6$ and vitamin $\mathrm{C}$ increase the nutritional value of the consumption of fresh carrots. Additionally, carrots contain calcium, iron and phosphorus in important concentration. Another value-added material of carrot is the carbohydrates. Carbohydrates are carbon, oxygen and hydrogen-containing organic compounds produced by plants during photosynthesis (Mandl 2006). The water- soluble carbohydrates (WSC) in the carrot are the fructose, sucrose and glucose, which form energy reserves in the carrot. Concentration of the WSC accumulation is a genetic property of the variety, but mostly it could be related to 
the storage capacity of carrot (Kiniry, 1993). The sweet, pleasant taste of the carrot is given by the mono- and disaccharides (glucose, fructose, sucrose) (Kovács and Géczi, 2011). The carrot also contains starch only in negligible amounts (Rubatsky et al., 1999). Fiber materials of carrot are mainly cellulose, and to a lesser extent, hemicellulose and lignin. They determine the mass of the carrot root that is the yield in economic terms (Schuh, 2011). In case of every cultivated plant, to reach the expected yield for a given variety, we must determine the optimal water, nutrient and other ecological claim of the plant by previous testgrowing, then we must use the most prominent nutrient supply technology for cultivation (Lantos, 2016).

\section{MATERIAL AND METHODS}

Our observations and test-growing were carried out in Üllés, Csongrád County, during the spring-summer field cultivation period in 2015. The growing region belongs to the temperate continental climate area. The weather is heavily extreme. When analysing the meteorological conditions of the last five years we found that the summer is warm or hot and slightly humid. Winters are relatively mild (average $-1,-5^{\circ} \mathrm{C}$ ) but humid, although the number of the boreal, frosty days were less than the national average. The annual temperature of the area was ranging between 10.5 and $11.5^{\circ} \mathrm{C}$, the annual precipitation was 540-580 mm. The $\mathrm{CO}_{2}$ concentration of the air was measured between 390-400 ppm during the growing season of carrot (own measurements). The soil of region is loose sandy soil (Table 5.). On the basis of the above we determined that Üllés and region meets to requirements of the open-field cultivation of carrot.

The designated observation area was divided into eight, equal-sized $100 \mathrm{~m}^{2}$ plots. During the soil preparation only plowing was used, as further soil disturbance could have resulted in soil compression in this case. Sowing was carried out with pneumatic precision seed drill on 25 of March. Cultivation was performed without ridge, with flat cultivation. Plant spacing was $8 \mathrm{~cm}$, row spacing was $20 \mathrm{~cm}$, twin spacing was $7 \mathrm{~cm}$, while sowing depth was $3 \mathrm{~cm}$. In four plots of eight we used organic manure $\left(4 \mathrm{~kg} / \mathrm{m}^{2}\right)$ as basic fertilization, and on the other four plots Nitrogen-Phosphorus-Potassium $12-11-18+B, Z n$ fertilizer $\left(0,04 \mathrm{~kg} / \mathrm{m}^{2}\right)$ was worked into the soil. Additional nutrient was supplied at the same time and in the same amount supply according to the demand of the plant (Napa $F_{1}$ hybrid carrot) together with irrigation.

Plot No. 1.: organic manure base, without any additional nutrient supplement.

Plot No. 2.: organic manure base, additional EC marked leaf fertilizer supplement.

Plot No. 3.: organic manure base, additional liquid plant hormone supplement.

Plot No. 4.: organic manure base, additional bacteria fertilizer supplement.

Plot No. 5.: fertilizer base, additional bacteria fertilizer supplement.

Plot No. 6.: fertilizer base, additional EC marked leaf fertilizer supplement.

Plot No. 7.: fertilizer base, additional liquid plant hormone supplement.

Plot No. 8.: fertilizer base, without any additional nutrient supplement.

The composition of agrochemical products are shown by Tables $1,-2,-3,-4$. At the end of growing season, after the harvest (105. day) the health status of all carrots were controlled by visual plant diagnosis. 3-3 carrots from each plot were further examined in a laboratory according the following factors: quantitative properties: average carrot body length, calculated yield $\mathrm{kg} / \mathrm{m}^{2}$. Quality properties: dry matter, crude protein, crude fiber, watersoluble carbohydrates (WSC), carotene, crude ash and moisture factor (Table 6.). The examination and determination of the composition of carrots was carried out by MSZ 6830/3 Hungarian Feed Codex II. Volume 4.1. ; Gerhardt D.7.a. FiberBag System and Anthron System in the laboratory of the University of Szeged, Faculty of Agriculture Hungary. Our measurements were performed in triplicate. The IBM SPSS Statistics 22 program was used for processing and publishing statistical data. Henceforward, out of the tested factors, only the results of the most dominant market materials (WSC, carotene, yield) will be analysed in this paper in detail. 
Table 1 - Compound of organic manure

\begin{tabular}{|l|l|}
\hline \multicolumn{1}{|c|}{ Components } & \multicolumn{1}{c|}{ Amount (\%) } \\
\hline water & 77.5 \\
\hline $\mathrm{P}_{2} \mathrm{O}_{5}$ & 0.24 \\
\hline $\mathrm{NH}_{4} \mathrm{NO}_{3}$ & 0.14 \\
\hline$\Sigma$ nitrogen & 0.45 \\
\hline $\mathrm{K}_{2} \mathrm{O}$ & 0.5 \\
\hline $\mathrm{CaCO}_{3}$ & 0.4 \\
\hline organic material & 20.3 \\
\hline
\end{tabular}

Table 2 - Compound of EK marked leaf fertilizer

\begin{tabular}{|l|l|}
\hline \multicolumn{1}{|c|}{ Components } & \multicolumn{1}{c|}{ Amount (\%) } \\
\hline EDDHSA & chelate \\
\hline $\mathrm{P}_{2} \mathrm{O}_{5}$ & 3.5 \\
\hline $\mathrm{S}$ & 3.6 \\
\hline$\Sigma$ nitrogen & 8 \\
\hline $\mathrm{K}_{2} \mathrm{O}$ & 3.5 \\
\hline $\mathrm{Cu}$ & 0.5 \\
\hline $\mathrm{MgO}$ & 0.3 \\
\hline $\mathrm{Zn}$ & 0.3 \\
\hline
\end{tabular}

Table 3 - Compound of the phytohormones contained leaf fertilizer

\begin{tabular}{|l|l|}
\hline \multicolumn{1}{|c|}{ Components } & \multicolumn{1}{c|}{ Amount (\%) } \\
\hline $\mathrm{CaCO}_{3}$ & 50 \\
\hline $\mathrm{P}_{2} \mathrm{O}_{5}$ & 8 \\
\hline $\mathrm{Se}$ & 5 \\
\hline$\Sigma$ nitrogen & 0.4 \\
\hline $\mathrm{K}_{2} \mathrm{O}$ & 0.3 \\
\hline $\mathrm{Cu}$ & 0.5 \\
\hline $\mathrm{MgCO}_{3}$ & 0.5 \\
\hline
\end{tabular}

Table 4 - Microorganism of the bacteria fertilizer

\begin{tabular}{|l|l|}
\hline Ascomycota & Trichoderma harzianum, Trichoderma asperellum \\
\hline Bacteria & Azobacter vinelandii, Streptomyces albus \\
\hline
\end{tabular}

Table 5 - Agrochemical compound of sandy soil before investigation

\begin{tabular}{|c|c|c|c|c|c|c|c|c|}
\hline Cultivation area & $\mathrm{pH}$ & $\begin{array}{c}\text { salt } \\
(\mathrm{m} / \mathrm{m} \%)\end{array}$ & fixity & $\begin{array}{c}\mathrm{CaCO}_{3} \\
(\mathrm{~m} / \mathrm{m} \%)\end{array}$ & $\begin{array}{c}\text { humus } \\
(\mathrm{m} / \mathrm{m} \%)\end{array}$ & $\begin{array}{c}\mathrm{P}_{2} \mathrm{O}_{5} \\
(\mathrm{mg} / \mathrm{kg})\end{array}$ & $\begin{array}{c}\mathrm{K}_{2} \mathrm{O} \\
(\mathrm{mg} / \mathrm{kg})\end{array}$ & $\begin{array}{c}\mathrm{NO}_{3}-\mathrm{NO}_{2}-\mathrm{N} \\
(\mathrm{mg} / \mathrm{kg})\end{array}$ \\
\hline Üllés & 7.2 & $<0.02$ & 28 & 1.7 & 0.94 & 820 & 70.3 & 13.4 \\
\hline
\end{tabular}

\section{RESULTS OF STUDY}

The results of our laboratory investigations were evaluated in the range of security intervals $95 \%, N=3 ; p=5 \%$ (Diagram 1.) Based on laboratory investigation we found that the effect of organic manure and fertilizer without other nutrient supply did not create significant difference in producing carotene substances in carrots. However, the nutrient supplement formulations increased the carotene concentration in case of carrots tested in organic manure base. The carotene concentration of carrots on plot No 5 . was significantly higher than that of the carrots treated with other fertilizer but their carotene concentration was less than that of the carrots treated with organic manure. The carotene investigation of carrots on eight plots, considering the best carotene results, was significantly outstanding during bacterial fertilizer supplement, irrespectively of the basic fertilizer.

The concentration of the water-soluble carbohydrate materials (WSC) was measured relatively at the same level. However, in case of the results of plot 6 a slightly higher WSC content was observed, but it was not significantly different. The concentration of watersoluble carbohydrate materials was not significantly different among the tested carrots. 
Uniform, extremely high yields could be harvested on the tested plots - according to the description of the breed standard (www.bejo.hu). Significantly superior yields were measured in case of basic fertilizer and bacteria nutrient supply on plot No. 5. It was determined for $\mathrm{kg} / \mathrm{m}^{2}$ (Diagram 1).

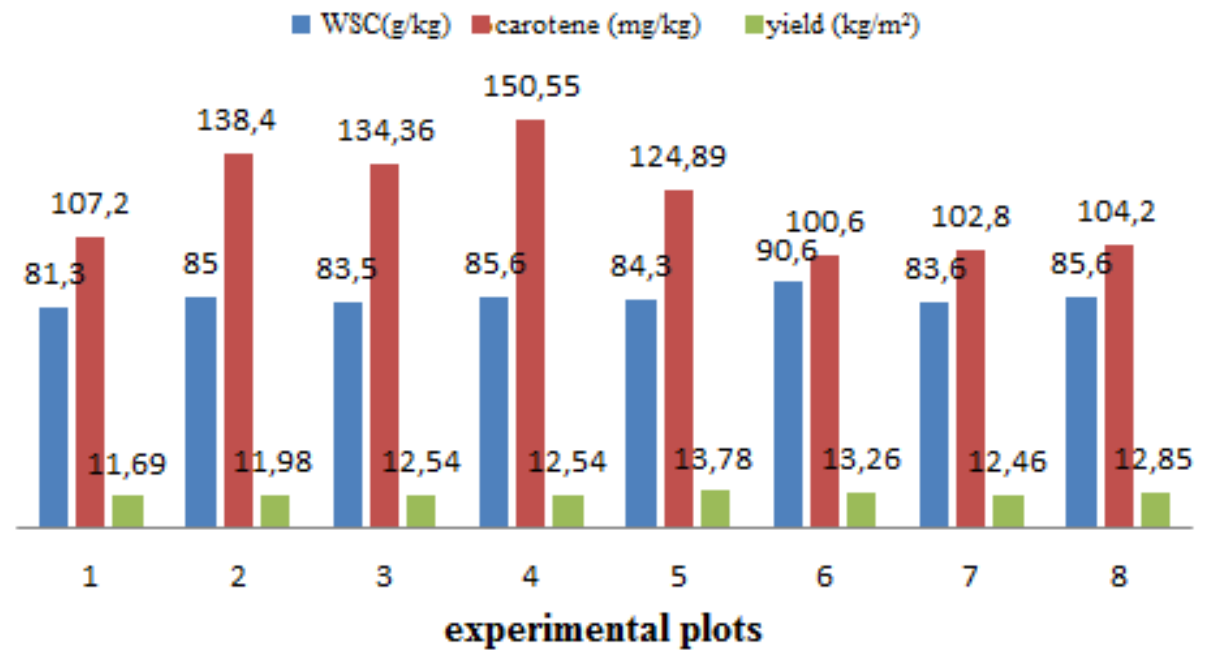

Diagram 1 - Development of the most important quality factors of test plots carrot

In case of the carrots harvested from the eight plots, our visual plant diagnosis did not identify any symptoms of nitrate accumulation, so further laboratory investigation was not necessary.

Table 6 - Results of other important components of carrots on average

\begin{tabular}{|c|c|c|c|c|c|}
\hline $\mathrm{n} / \mathrm{n}$ & Moisture factor & Dry matter $(\%)$ & Crude protein $(\mathrm{g} / \mathrm{kg})$ & Crude ash $(\mathrm{g} / \mathrm{kg})$ & Root growth $(\mathrm{cm})$ \\
\hline plot No. 1. & 0.15 & 13.86 & 9.13 & 13.14 & 18.5 \\
\hline plot No. 2. & 0.28 & 25.83 & 20.1 & 24.63 & 18.6 \\
\hline plot No. 3. & 0.18 & 16.46 & 11.4 & 16.14 & 20.4 \\
\hline plot No. 4. & 0.55 & 16.81 & 11.1 & 15.05 & 20.1 \\
\hline plot No. 5. & 0.19 & 16.67 & 14.4 & 15.2 & 21.4 \\
\hline plot No. 6. & 0.15 & 14.37 & 10.5 & 12.51 & 21.9 \\
\hline plot No. 7. & 0.15 & 16.6 & 11.5 & 12.02 & 22.6 \\
\hline plot No. 8. & 0.21 & 18.8 & 14.5 & 18.35 & 20.2 \\
\hline
\end{tabular}

Nitrates are accumulated carcinogenic nitrosamines in plants. The carrot is moderately susceptible to nitrate accumulation, i.e. its nitrate content is $500-1000 \mathrm{mg} / \mathrm{kg}$ on average. However, since it is used also as baby food in significant quantities, therefore the nitrate accumulation is very critical (Uzoni, 2001). The nitrates $\left(\mathrm{NO}_{3}\right)$ themselves are not toxic, but if they are not excreted from the body of the infant with a normal rapidity, they could develop into nitrites $\left(\mathrm{NO}_{2}\right)$. Nitrites are powerful poisons and they are particularly dangerous for infants younger than 8 months. They can cause methaemoglobinaemia in their body (Tulupov et al., 2001; Kazanets, 2009). The Mauser Seed Catalogue ('95/96 spring edition) dealt with the results of a French medical research, that the nitrate contained by the plant did not transfer into nitrite in the stomach of older babies, so it did not become carcinogenic nitrosamine. This is in line with the previous experience of paediatricians, that methaemoglobinaemia is caused by improperly washed baby bottles. It is also analogous with the epidemiological experiment, which was carried out in Britain. Several cancer patients were therapeutic fed with high doses of fertilized vegetables and fruits. During the investigation the concentration of nitrate of carrot and lettuce was higher then allowed. Nonetheless the vegetables consumption had beneficial effects on the condition of the patients (Gemüse Zeitung, 1998). 


\section{CONCLUSIONS}

Based on the results of the test growing of Napa $F_{1}$ carrot hybrid, in respect of the soil and meteorological conditions of Üllés and its surroundings, we can conclude the following.

1. Our investigations into the production of carotene proved that the organic manure basic and the additional bacteria nutrient supplement had the largest effect on increasing the carotene concentration in carrots. Carotene-result of plot No 4. was outstanding (Diagram 1.). Nagy et al., (2013) found high concentrations of carotenoids in different corn hybrids treated by Azobacter strains. At the same time, according to a study by Abd el-Baki et al., (2014) increased $\mathrm{K}^{+}$ion concentration was observed in the roots and shoots of leguminous (Vicia faba L.) treated with Trichoderma filamentous fungus. All in all, we could conclude that the micro-organism of bacteria fertilizer we used had the most intensive effect on the uptake of $\mathrm{K}^{+}$ion in neutral soil $(\mathrm{pH} 7.2)$.

2. The water-soluble carbohydrate (WSC) concentrations were almost identical in context of the eight parcels. Therefore it can be assumed that the balanced amount of water-soluble carbohydrate materials (WSC) is a character of the variety, which had evolved during the breeding of Napa $F_{1}$ carrot, and this character has already been stabilized. The results of a previous research by the Rona Cooperative (Tömpe, 2011) also pronounced the above-theaverage and uniform water-soluble carbohydrate (WSC) concentration of Napa $F_{1}$ carrot variety.

3 . In the respect of the yield our aim was to determine the weight of the carrots. Among the tested eight parcels the yield-result of plot No. 5 was outstanding (Diagram 1.). In the development of the root as the first significant vegetative part of the plant the cell construction work of ammonium $\left(\mathrm{NH}_{4}{ }^{+}\right)$, nitrate ions $\left(\mathrm{NO}_{3}{ }^{-}\right)$and phosphate ions $\left(\mathrm{H}_{2} \mathrm{PO}_{4}{ }^{-}\right)$are of the greatest importance. These ions were all present both in the fertilizer and the organic manure worked into the soil. Rifaat et al., (2005) proved in their study that the Streptomyces albus bacteria can activate the transport of water and nutrients up taken from the soil in xylem. Kátai (2011) proved that the Streptomyces albus microorganism will affect the faster decomposition of organic matter of soil, and the uptake of phosphorus by plants. Our research analysed in our study also proved that the above-mentioned macro elements and bacteria nutrient supplement could be better utilized thus increased the weight of carrots.

4. The nutrient supply protocol on plots of No. 4 and 5 were repeated on cultivated areas with similar conditions (Domaszék, Mórahalom) in 2016. Our results were almost similar. The differences between the tested substances did not exceed the $5 \%$ (Diagram 2).

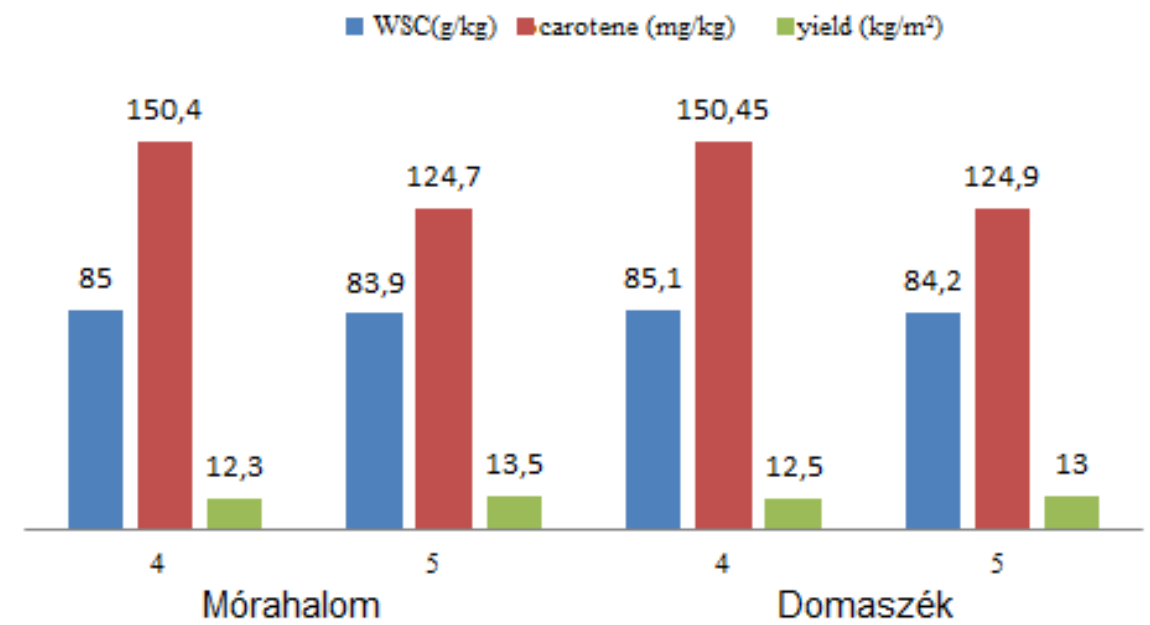

Diagram 2 - Results of repeated investigation of the other two cultivation areas

After the summary of the results of our investigation we can state that all three products were suitable for achieving the good quality and optimal yield in open-field carrot cultivation. We can also state that in case of growing Napa $F_{1}$ carrot hybrid in poor fertile sandy soil the 
basic fertilizer or/and organic manure additional bacteria nutrient supplement could result in outstanding carrot yield.

In our nutrient supply investigation, under the above-mentioned meteorological and soil conditions, the agrochemical technology used on plot No. 5 was the most effective.

\section{ACKNOWLEDGEMENTS}

We would like to thank to colleagues of laboratory of University of Szeged Faculty of Agriculture, together with producers of nutrient supply products: Agrosolution, Bioego and Zöldpajzs.

\section{REFERENCES}

1. Abd El-Baki,- Mustafa, D. (2014): The potentiality of Trichoderma harzianum the adverse effects of salinity in faba bean plant. Acta Biol Hung. 2014 Dec;65(4):451-68.

2. Gemüse Zeitung (1998) 1-12. Verlag. Gemüse ist mehr als ein Nahrungsmittel. BRD.

3. Kazanets E.G. 2009. Methemoglobinemia. Detskaia bol'nitsa. Children Hospital. No.1. 38-42 Russia.

4. Kátai, J. (2011): Talajökológia. Baktérium alapú készítmények a talaj biológiai aktivitásának javítására. http://www.tankonyvtar.hu

5. Kiniry, J. R. (1993): Nonstructural carbohydrate utilization by wheat shaded during grain growth. Agronomy Journal. 85, 844-849.

6. Kovács, A.- Géczi, L. (2011): Gyökérzöldségek termesztése. Mezőgazda Kiadó, Budapest.

7. Lantos, F. (2016): Agrochemistry for Bsc students. ISBN 987-963-306-400-9.

8. Láng, F. (2003): Növényélettan - Növényanyagcsere I-II. kötet. ELTE. Budapest.

9. Linus Pauling Institute (2009): Micronutrients Information Center: $\alpha$-Carotene, $\beta$ Carotene, $\beta$-Cryptoxanthin, Lycopene, Lutein, and Zeaxanthin. Oregon State University. www.oregonstate.edu

10. Mandl, J. (2006): Orvosi kémia és biokémiai gyakorlatok. Semmelweis Kiadó. Budapest.

11. Nagy, L. G.- Nagy, L.- Lévai, L.- Veres, SZ.- Bodnár, K.- Tóth, B. (2013): A baktérium tartalmú biotrágyák hatása a növénytermesztésben. 55. Georgikon Napok Tudományos Konferencia. Kivonat-kötet 73.

12. Olson, J. A. (2006):Vitamin A. Office of Dieatary Supplements webside. USA.

13. Rifaat, H.M.- Nagieb, Z.A.- Ahmed, Y.M (2005): Production xylanases by Streptomyces species and their bleaching effect on rice straw pulp. Applied Ecology and Environmental Research. 4(1):151-160. ISNN 15891623.

14. Rubatsky, V.E.- Quiros, C.F.- Simon, P.W. (1999): Carrots and Related Vegetable Umbelifere. CABI Publishing. 294.

15. Schuh, M. (2011): Carrot Grow Underground. Pebble Books. ISBN 978-142-966-1850.

16. Tömpe, A. (2011): Negyvenkét sárgarépa. Kertészet és Szölészet. 60. évf. 47. szám. 1013.

17. Tulupov, V. P.- Prikhod'ko, E. I.- Fomichenko, E. I. (2001): Toxicological hygienic assessment of nitrates in food products. Voprosy Pitanija. 70(2), 4-32.

18. Uzoni, H. (2001): Sárgarépafajtáknál alkalmazott eltérő termesztéstechnológiák hatása a beltartalmi értékekre. PhD értekezés. SZIE Zöldség- és Gombatermesztési Tanszék Budapest. 